\title{
Preservice Teachers' Perceptions of the Pedagogical Function of Heroes and Hero Stories
}

\author{
Kenneth V. Anthony ${ }^{1} \&$ Melissa Baneck ${ }^{1}$ \\ ${ }^{1}$ Mississippi State University, Mississippi State, MS, USA \\ Correspondence: Kenneth V. Anthony, Department of Curriculum, Instruction, and Special Education, \\ Mississippi State University, MS, 39762, USA. Tel: 1-662-325-4870. E-mail: kva3@msstate.edu
}

Received: May 19, 2020

doi:10.5539/ies.v13n12p1
Accepted: July 26, $2020 \quad$ Online Published: November 23, 2020

URL: https://doi.org/10.5539/ies.v13n12p1

\begin{abstract}
Teachers serve as gatekeepers to the implementation of curriculum in their classroom (Thornton, 2005). Their beliefs about a topic and the wider political environment can influence what they teach. To this end, our goal was to investigate whom preservice teachers identify as heroes and why, which heroes should be included in the curriculum, and how this might influence instruction of the NCSS theme Individual Development and Identity. This study was an exploratory study using the qualitative methods of an open-ended survey and focus group. We were guided by the research question: How do preservice elementary teachers conceptualize heroes? The participants were elementary preservice teachers in their final semester prior to teacher internship. We surveyed participants to determine their perceptions of heroes. We conducted a follow up focus group with five participants. The participants conceptualized heroes as serving a pedagogical function. We learned that these preservice teachers had a balanced concept of heroes and considered heroes valuable to the school curriculum. They saw heroes as role models for students to imitate. Of interest to the study of heroes in the social studies curriculum, these preservice teachers were able to overcome the barrier of the flawed hero. Rather than shifting away from teaching heroes and focusing on heroic actions as Barton and Levstik (2004) recommend, they were able to keep the curricular gate open (Thornton, 2005) to teaching heroes by developing the concept of the gray hero.
\end{abstract}

Keywords: heroes, preservice teachers, individual development, identity, social studies

\section{Introduction}

The stated goal of social studies in the National Council for the Social Studies (NCSS) is to "promote civic competence" (NCSS, 2010, p. 2). When NCSS published the National Curriculum Standards for Social Studies in 1994 and updated them in 2010, they organized the curriculum into ten themes. NCSS did not organize the themes around the traditional four subjects often associated with the field: civics, history, economics, and geography. Instead, the idea was that the ten themes would serve as "strands" incorporated throughout a social studies program. In this study, the theme we are concerned with is Individual Development and Identity. The NCSS standards state that, "Through this theme, students examine the factors that influence an individual's personal identity, development, and actions" (p. 4). This theme closely relates to the theme - Individuals, Groups, and Institutions. When we think of civic competence, it is usually in the sense of existing institutions that individuals are learning about in their society or community. In the American experience, we think of this as young people learning what it means to become a member of a democratic society. However, we should also consider how young people learn to develop an identity within that society, how they move from dependency to independence, and how they transition from childhood to adulthood.

\subsection{Individual Development and Identity in the Social Studies}

The study of the development of the individual in society is explicitly called for in the NCSS Standards. When we read the various descriptions of the Individual Development and Identity theme in the NCSS Standards, we are confronted with the problem of how to help students understand how individuals develop and what that means in their own lives. We are also challenged to help students develop skills that help them set and accomplish goals, to confront and overcome challenges, and to understand that though they are an individual, they have responsibilities to others in the society (NCSS, 2010). 
Teachers serve as gatekeepers to the implementation of curriculum in their classroom (Thornton, 2005). Their beliefs about a topic and the wider political environment can influence what they teach. We were particularly interested in how the study of heroes and heroines (for the rest of the paper we will use heroes to denote both male and female heroes) can help teachers teach the social studies theme Individual Development and Identity within a social studies program. To this end, our research goal was to investigate how preservice teachers conceptualize heroes and why, which heroes they believed should be included in the curriculum, and how this might influence instruction of the NCSS theme Individual Development and Identity.

\subsection{Teachers as Gatekeepers to Teaching About Heroes}

To illustrate the potential role of teachers as gatekeepers in teaching heroes, consider the case of Thomas Jefferson. Barton and Levstik (2004) make a convincing argument that studying heroes is problematic because many heroes have serious flaws. In the context of American democracy, the practice of owning slaves conflicts with American ideals. To counter the problem of potential disappointment, they argue for a shift from "the concept of heroes" to a "focus on heroic actions" (p. 105). Barton and Levstik are correct in identifying the problem of disappointment. In our elementary social studies methods courses, students have voiced concerns about Jefferson because of slavery. These preservice teachers might agree with Barton and Levstik (2004), disqualify Jefferson from hero status, and exclude him from their classroom instruction. This is problematic because in order to teach early U.S. History accurately, Jefferson must be included. Additionally, there are elements of Jefferson's life that are valuable for students to learn. One element of his life is his maturation from adolescence to adulthood, which could serve as both an example and a non-example for students. The problem is not the criticism of Jefferson over his of his active participation in slavery, the problem is the potential teacher exclusion or limited instruction of Jefferson based on these criticisms. The other problem is a misunderstanding of the concept of hero.

\subsection{Heroes and Heroines}

Joseph Campbell (1949/2008) stated the hero "is symbolical of that divine creative and redemptive image which is hidden within us all, only waiting to be known and rendered into life" (p. 39). Heroes teach us to look outside of ourselves and to think without limitations. Campbell (1991) claimed that heroes are significant because they challenge us and give us the "courage to face trials" and create new possibilities in life (p. 49). Hero stories describe the development of children into adults. Hero stories are about overcoming hardships, sacrifice, accepting challenges, and contributing to the greater good of the society (Campbell, 1949/2008; Campbell, 1991). For this reason, we should teach about mythological as well as historical and modern heroes in schools (Baneck \& Anthony, 2016).

The purpose of teaching heroes is not to give students unattainable examples of figures who only display extraordinary qualities, for even the Greek gods and heroes had flaws. Heroes used in education (whether mythological, historical, or modern) should give students examples of significant acts others have performed in the past and present, regardless of whether or not they lived a flawless life (Baneck \& Anthony, 2016).

The idea of teaching heroes is not new. Plutarch is compared to a portrait painter for his skill in taking what readers already know and "creat[ing] an inspiring portrait" (Scott-Kilvert, 1965, p. 12). To create a portrait, drama was added and personality examined. Plutarch aimed to "bring out the moral pattern in his hero's career, the movement from virtue to vice or the contrary" (Scott-Kilvert, 1965, p. 12). He believed no man stood still in virtue, and therefore, must either progress or decline. Either way, the hero should be regarded as a model for what to do or what not to do. This type of analysis within a classroom meets the definition of character education, for its aim is to focus students on virtuous acts.

Hoge (2002) defined character education as "any conscious or overt effort to influence the development of desirable individual qualities or traits" (p. 104). The Character Education Partnership (CEP) in its Eleven Principles of Effective Character Education identified that there are "important core ethical values- such as caring, honesty, fairness, responsibility, and respect for self and others -that form the basis of good character." The CEP principles explain that every member of the school staff must display these values and model good character for students in order to participate in character education successfully. Critiquing the CEP's principles, Hoge pointed out that "democracy is mentioned only once in the eleven principles...character education advocates have focused more on the initial development of basic 'good person' traits" (p. 104). Yet to develop a well-rounded student who will be a member of a democracy, education tasks must be taught as well. Hoge listed a few examples, including, "inspecting the morality and allegiances of candidates for public office; becoming adept at conducting a values centered analysis of public issues; developing a strong commitment to defening the civil rights of minorities" (p. 104). Hoge also argued that students should be taught in a way that is based on and extends the character traits laid out by the CEP, and they "should be urged to examine the lives and actions of 
key historical figures for the same traits" (p. 107). These tasks require students to consider character within a democratic setting and use that knowledge to guide their participation in a democratic society. The writings of Plutarch, the character education advocated by Hoge (2002), and the CEP can be critical elements in a social studies curriculum. However, they require the inclusion of heroes (mythological, historical, and modern) into instruction.

Using heroes as a part of character development is a logical step, as long as heroes are examined and their merits are discussed. Stories of heroes are likely to engage students in discussions about what it means to be a hero (Baneck \& Anthony, 2016). Rather than students merely studying the acts of heroes, an in depth analysis of personal characteristics can be made. Students can ask questions and reason about what qualifies or disqualifies a person from being a hero (Baneck \& Anthony, 2016). Students gain positive skills necessary for character development through the cross-examination of heroes, as advocated by Hoge (2002) and practiced by Plutarch.

The study of heroes and hero stories provides patterns or models that students can use to navigate through individual development. This is evident in Campbell's discussion of a hero. He described a hero as "the man of self-achieved submission" (1949/2008, p. 11). In a later work, Campbell wrote that the "hero is someone who has given his or her life to something bigger than oneself" (1991, p. 151). For those in the field of social studies, this is of interest. We want our students to develop into individuals who give back to their society, who are good citizens, and who possess the knowledge, skills, and attitudes necessary to continue our democratic society. This requires the development of individuals who are willing to move beyond mere concern for self-preservation to concern and action for a greater good. However, how do we develop these individuals? Campbell (1949/2008; 1991) argued that heroes are role models. Learning about heroes helps young people make the transition from childhood to adulthood. Campbell (1991) described myths and stories of heroes as having a "pedagogical function... that can teach us "how to live a human lifetime under any circumstances" (p. 39). It helps to change their perceptions of themselves, the world, and their place in the world. If the heroes are the models, then we should include them in our teaching. If teachers are reluctant to teach about heroes because of personal beliefs about flawed heroes, outside cultural pressures, or an inaccurate view of the concept of heroes, there is a potential that our students will miss out on role models that will help them transition into competent adult members of our society.

\subsection{Related Research}

Previous research related to our work focused on whom children and adolescents identify as heroes (Anderson \& Cavallro, 2002; Bricheno \& Thornton, 2007; Freedman-Doan, 1997; White, 1999), and how hero stories and myths are used for pedagogical purposes (Anastaspoulos, Soumaki, \& Anagnostopoulos, 2010; Apostolou \& Apostolou, 1997; Campbell, 2013).

Anderson \& Cavallro (2002) studied the effect of media on children's choices of heroes. They used surveys to collect which forms of media participants used the most. They then asked students to record their heroes and role models, both real and imagined. Their research found that the children most often selected their parents, implying that even in a media driven world, parents still have a significant impact on the characteristics their children value. This study is important to our work as we seek to advocate for the use of heroes and hero stories in the social studies classrooms, but also to determine whom future teachers see as heroes.

Bricheno and Thornton (2007) conducted a study to determine who students aged 10-16 selected as role models and why. Similar to Anderson and Cavallro (2002), many of the students (almost one third) chose one or both parents as a role model. Interestingly, for a study focusing on myths that tend to have more male characters and heroes, gender did have a significant impact on role selection, as boys mainly chose male role models and girls mainly chose female role models. Finally, an incredibly small percentage selected teachers as role models. This study reinforces the idea that students tend to select role models or heroes who are closest to them.

The largest study reviewed for our purposes was by Freedman-Doan (1997). Freedman-Doan conducted a study with 958 eighth graders, roughly half girls and half boys, to examine differences between ethnic groups and if self-esteem related to a student's chosen hero. The questionnaire included questions related to self-esteem, ethnic identity, and the importance of race in selection of heroes. The students also had to identify a hero they knew and one they did not know. Freedman-Doan reported that self-esteem and ethnic identity did not have a great impact on a student's choice of hero, but there were differences based on race. About one fourth of the students had a difficult time selecting a famous hero. Similarly, to the findings of Anderson and Cavallaro (2002) and Bricheno and Thornton (2007), Freedman-Doan reported that parents were critical to developing a student's identity, as they were the most often identified heroes.

White (1999) studied students' conceptions of heroes with a sample of 590 students from kindergarten to $12^{\text {th }}$ grade. The students were surveyed on their concept of hero and were asked, "Who is your hero?" The study found 
that students' definitions depended on age, but more importantly for this study, that parents were listed most frequently for students of all ages.

Several of the studies on whom students identify as heroes informed our study. One was the importance of parents as heroes and in the formation of individual identity. Secondly, although we live in a time dominated by media and famous people, students may not see famous people as heroes and role models, preferring instead role models they actually know. Finally, we were able to amend our research methods by asking our preservice teachers to identify both known and unknown heroes, as Freedman-Doan (1997) did in their research.

The three studies about how heroes and myths can be used pedagogically reinforced Campbell's (1991) assertion that hero and myth stories can play a critical role in individual development. Anastaspoulos, Soumaki, and Anagnostopoulos (2010) reported that adolescent experiences and thought processes can and should be directly related to mythology. Echoing Campbell (1991), they claimed that myths provide meaning, and without this meaning, students might have trouble finding their personal identity. Of interest to our study, they expanded the concept of hero beyond mythical heroes to include modern heroes as important to individual development.

Apostolou and Apostolou (1997) argued that heroes are a good choice for teaching ethics and presented examples of how teachers have done this in the past. Additionally, they illustrated how teaching ethics through heroes fostered critical thinking, as students would be required to identify heroes and provide a justification for their selection. Their work was interesting because they conducted their study in university accounting classrooms. They used heroes to introduce the concept of ethics, which illustrates the broad pedagogical application of heroes and myths. Though our focus is using myths in the elementary or middle school setting, they are universal enough that they can apply to adults in a university accounting program.

Campbell (2013) argued that myths and hero stories could be used to teach leadership principles, because both myths and leadership principles are universal and timeless. Campbell argued that myths serve as models of both good and bad leadership characteristics. This is important to our work because some scholars (Barton \& Levstik, 2004; Dunn, 1991) question the use of heroes precisely because they are flawed. They fear that this will lead to future disappointment and confusion with students.

These three studies contribute to our study, as they illustrate the broad role that myths and hero stories can play in individual development, whether it is, with adults in an accounting program, leaders looking for positive and negative models, or adolescents looking for models of how to cope with growing up. The lessons learned from myths are enduring and have broad application. These studies also reinforce the contention of Campbell (1991), that myths are central to the development of individual identity. Finally, they address the concerns of some (Barton and Levstik, 2004; Dunn, 1991), that studying heroes can lead to disappointment, by actually identifying the pedagogical function of the negative examples of heroes (Campbell, 2013). We believe that the theory and research we have outlined supports the inclusion of myths and heroes in elementary and middle school classroom instruction and can support the goal of teaching the NCSS Theme: Individual Development and Identity.

\subsection{The Current Study}

The previous research focused on students' perceptions of heroes and how myths and hero stories are used for pedagogical purposes. We sought to add to the research by studying preservice teachers' perceptions of heroes. In the elementary social studies curriculum, individuals who have shaped or contributed to their community serve as examples of good citizenship (Chapin, 2009). Additionally, we argue they should be used to teach the NCSS Theme: Individual Development and Identity in a social studies program. However, who do future teachers perceive as heroes? If it is important to teach about heroes (or heroic actions) then it is important to know whom preservice teachers identify as heroes, because this will influence what or whom is taught in the classroom (McCowan, 2009; Thornton, 2005). The following research question framed our study: How do preservice teachers conceptualize heroes? The research question was supported by the following questions:

1) Whom do preservice elementary teachers identify as heroes that should be included in the social studies instruction?

2) Whom do preservice elementary teachers disqualify as heroes?

3) How do preservice elementary teachers define hero?

4) What is their rationale for including or excluding an individual as a hero?

\section{Methods}

\subsection{Study}

This study was an exploratory study using the qualitative methods of an open-ended survey and a focus group. It 
was exploratory in that we sought to discover themes related to how these preservice teachers conceptualize heroes for use in further research. Our research question was how do preservice elementary teachers conceptualize heroes?

\subsection{Participants}

The participants $(n=31)$ were elementary preservice teachers in their final semester prior to teacher internship. $99 \%$ of the participants were female and over $90 \%$ were white. All participants were undergraduates in the elementary education program at a research university in the Southeast United States with over 18,000 undergraduates. There were over 400 students in the elementary education program. We recruited participants from the senior elementary social studies methods courses. We offered no incentives to participate and participation was voluntary. The total number of students recruited was 43 . Thirty-one students agreed to participate and provided complete data on the survey. Five agreed to participate in the focus group.

\subsection{Data}

We collected data using two qualitative methods: an open-ended survey of the 31 participants and a follow up focus group interview with 5 of the original participants. We incorporated Freedman-Doan's (1997) concept of known and unknown heroes into our survey. Participants completed the open-ended survey using an online portal that recorded their answers in a spreadsheet, which facilitated the sorting and analysis of data. The survey asked participants to list 5 personal heroes (people they actually know), 5 public heroes (people that they do not know), and 3 heroes that should be taught in schools. We also asked the participants to provide a rationale for each hero listed.

We conducted a follow up focus group, with five participants, to refine our understanding of how these preservice teachers conceptualize heroes and about the pedagogical use of heroes. The focus group was a semi-structured interview that allowed the participants to answer the questions and expand the conversation. The questions initially asked during the focus group were:

1) How do you decide who is a hero?

2) Why is it important to have heroes?

3) What might disqualify someone from being a hero?

4) Should we teach heroes in schools?

During the focus group interview, one researcher conducted the interview and recorded responses on large white posters. The other researcher took detailed notes of participant responses.

\subsection{Data Analysis}

We analyzed participant responses and organized them into categories that emerged from the data. We did not develop categories a priori, but rather analyzed the data for themes that emerged from participants' responses. Researchers individually coded the data for each question to identify categories. We then reconciled differences through a process of sorting examples into each category to reduce overlap between the categories (i.e. work to limit an example hero into one category if possible). This enabled us to reduce categories or create new ones as necessary during analysis. The resulting categories were place into tables. We then conducted counts to determine the frequency of hero or rationale listed in each category. We present the results below.

\section{Results}

\subsection{Personal/Known Heroes}

The participants listed heroes that they knew (known/personal heroes). The known/personal heroes listed fit into four categories: family and friends $(n=110)$, military $(n=15)$, teacher/coach $(n=9)$, and pastor/church members $(n=6)$ (See Table 1). Rationales (See Table 2) included personality traits (strong, loving, encouraging, selfless, brave, hardworking) $(=81)$, overcoming difficulties (disease, disability) $(n=24)$, inspirational/impact $(\mathrm{n}=15)$, protecting others/fighting for country $(n=15)$, and helping others $(n=12)$. These personal heroes were significant because they exhibited attributes that others would want to possess and made lasting impacts on the participants' lives. Of interest, participants selected personal heroes for personality or personal characteristics rather than significant contributions to the community.

\subsubsection{Public Heroes}

Next, the participants listed public heroes (or heroes they did not know). Civil rights figures were the individuals most identified as public heroes because they helped others and were inspirational $(n=38)$. Two categories of inspirational figures were found: those that faced hardships $(n=36)$ and those of strong faith $(n=20)$. These and 
other identified categories are listed in Table 3.

The participants identified public figures from a variety of fields including media personalities, musicians, actors, and other celebrities. For our purposes and analysis, we focused on the heroes who have more to contribute to individual development in a traditional sense. We acknowledge that there may be much to learn from the study of celebrities, but that was not a part of this study.

The rationales (See Table 4 ) for public heroes focused on inspiring others $(n=28)$, improving society $(n=51)$, risk [military $(n=20)$ and non-military $(n=8)$ ], and perseverance $(n=22)$. Public heroes' achievements were less about personality and more about actions. The primary reason public heroes were listed was achievement and inspiration.

Within the discussion of heroes in both their surveys and the focus group, the idea of a "gray" or flawed hero surfaced. As one participant explained, "You can have bad qualities, but things need to balance out." This idea of "balancing out" echoes back to Plutarch's analysis of the progress and decline of virtue in people's lives. It also echoes the idea of character education (Hoge, 2002) as an analysis or examination of the good and bad characteristics of historical figures. Participants acknowledged that heroes are not always perfect and that teaching heroes can change the mindset of students to show that they too can grow into heroes. These participants felt teachers should teach heroes with flaws and all, as this contributes to the development of the individual student. This is similar to Campbell's (2013) belief that learning about both the good and bad characteristics of heroes can serve to develop leadership.

Table 1. Personal/known heroes

\begin{tabular}{llc}
\hline Category & \multicolumn{1}{c}{ Examples } & Count \\
\hline Military & Grandfather, great-grandfather, soldiers, dad & 15 \\
Family and Friends & $\begin{array}{l}\text { Dad, mom, grandmother, neighbor, doctor, } \\
\text { sister, grandfather }\end{array}$ & 110 \\
Teacher/Coach & $\begin{array}{l}\text { University faculty member, high school } \\
\text { teacher, all teachers, cheer coach }\end{array}$ & 9 \\
Pastor/Church members & Member, pastor & 6 \\
\hline
\end{tabular}

Table 2. Rationales for heroes (known)

\begin{tabular}{llc}
\hline Rationale & \multicolumn{1}{c}{ Examples } & Count \\
\hline \multirow{2}{*}{ Protect Country/Fought } & Fought in WWII, protect our country, risk & 15 \\
& life, war hero, wounded in action & 12 \\
Nelp others & $\begin{array}{l}\text { Nurse, always helping others, doctor, runs } \\
\text { an orphanage }\end{array}$ & 15 \\
& Changed my views, relationship with God, \\
public speaker/writer for Christianity, & \\
Inspirational/Impact & ministry to be a teacher, missionary, \\
& Cancer, disability, illness, tumor, rough \\
home life & 24 \\
Overcame difficulties & Strong, caring, loving, encouraging, \\
Personality aspects & selfless, leader, brave, hardworking, faith, \\
& passionate & 81 \\
\hline
\end{tabular}

\subsubsection{Pedagogical Heroes}

Participants were able to list heroes who should be included in the curriculum (See Table 5). Many of the heroes identified are key historical figures in social studies and history curricula. As would be expected, all were public heroes. Heroes to be taught were mainly civil rights figures $(n=65)$. Other pedagogical heroes included United States Presidents $(n=19)$ and Innovators/Thinkers $(n=10)$. What most distinguished these individuals as heroes was their public contributions that improved society or inspired others. The rationales (See Table 6) for being a pedagogical hero fell into four groups: serving others $(n=5)$, personal characteristics (determination, overcoming difficulties) ( $n=14)$, leadership (great president, charismatic) $(n=12)$, and public contributions (fought for civil rights, technological advances) $(n=68)$. The primary reason pedagogical heroes were listed was their contribution 
to the greater community. The participants stated that heroes included in the curriculum should also include lesser-known public and historical figures to broaden the concept of hero and to serve multicultural curriculum purposes.

Table 3. Categories of public heroes (not known)

\begin{tabular}{|c|c|c|}
\hline Category & Examples & Count \\
\hline Military, police, firemen & $\begin{array}{l}\text { Soldiers, first responders of } 9 / 11 \text {, Marcus } \\
\text { Luttrell, Chris Kyle, policemen and firemen } \\
\text { of } 9 / 11 \text {, Noah Galloway, Michael Murphy }\end{array}$ & 22 \\
\hline Church leaders/Faith & $\begin{array}{l}\text { Beth Moore, Sarah Young, John Calvin, Pope } \\
\text { Francis, Mother Theresea, Billy Graham, Joe } \\
\text { White, Paul, Martin Luther }\end{array}$ & 20 \\
\hline Celebrity/TV Personality & $\begin{array}{l}\text { Jennifer Aniston, Shonda Rhimes, Taylor } \\
\text { Swift, Oprah, Ellen Degeneres, Jennifer } \\
\text { Lawrence, Demi Lovato }\end{array}$ & 17 \\
\hline Fictional Characters & $\begin{array}{l}\text { Olivia Pope, Lorelai Gilmore, Monica Gellar, } \\
\text { Robin Hood }\end{array}$ & 6 \\
\hline Hardships & $\begin{array}{l}\text { Malala Yousafzai, Michaela DePrince, } \\
\text { Chesley Sullenberger, Anne Frank, Victoria } \\
\text { Soto, Elisabeth Elliot }\end{array}$ & 36 \\
\hline Presidents/Military leaders & $\begin{array}{l}\text { Winston Churchill, Franklin D. Roosevelt, } \\
\text { Ronald Reagan, John F. Kennedy }\end{array}$ & 6 \\
\hline Civil Rights & $\begin{array}{l}\text { Jesse Owens, MLK Jr., Eleanor Roosevelt, } \\
\text { Rosa Parks, Mahatma Gandhi, Harriet } \\
\text { Tubman, Nelson Mandela }\end{array}$ & 38 \\
\hline Inventors/Innovators & Bill Gates, Walt Disney & 5 \\
\hline Miscellaneous & Jamie Oliver, University President, doctors & 2 \\
\hline
\end{tabular}

Table 4. Rationales for public heroes (not known)

\begin{tabular}{|c|c|c|}
\hline Rationale & Examples & Count \\
\hline Improving or bettering the world (social) & $\begin{array}{l}\text { Activist for civil rights, helped poor, } \\
\text { against racial discrimination, activist for } \\
\text { female education, helping teachers and } \\
\text { schools, helping women in Africa, pulled } \\
\text { America out of depression, lead country }\end{array}$ & 51 \\
\hline Inspirational (spiritual/personal) & $\begin{array}{l}\text { Passionate, encouraging, impacts lives, } \\
\text { stand up for religious beliefs, donates } \\
\text { money to charity, service and faith, hero } \\
\text { of the faith, martyr }\end{array}$ & 28 \\
\hline Military risk life & $\begin{array}{l}\text { Risk lives to protect us, heroic actions, } \\
\text { American hero, defending human values, } \\
\text { fought for country }\end{array}$ & 20 \\
\hline Non-military risk life & Saved lives, gave their life & 8 \\
\hline Perseverance & $\begin{array}{l}\text { Hardworking, overcoming difficulties, } \\
\text { dedication }\end{array}$ & 22 \\
\hline
\end{tabular}

\subsection{Heroes and Individual Development and Identity}

The participants conceptualized heroes as serving a pedagogical function. The participants identified considerations for teaching about heroes. They identified traits of heroes that students should aspire to develop. These preservice teachers saw heroes as models: "Heroes are important because they give inspiration so you can impact people and give meaning to life." Teaching heroes can also change the mindsets of students by showing that "fighting doesn't make a hero, but standing up to a bully does." They saw historical figures as having greater value as models than as mere names in a textbook associated with a date or historical event. Elementary and middle school students can study their lives and learn things that will help them develop into adults and fully functioning 


\section{citizens of their nation.}

The participants believed that moral heroes should be taught at a young age because students can "understand the moral figures more." The moral figures provide students with examples of how to be courageous, overcome adversity, and contribute to the community. However, gray heroes are relevant because "John F. Kennedy might not be a family hero, but he is an American hero." It all comes down to a gray hero's action and making sure the "facts are age appropriate." Participants suggested teaching with both common heroes and lesser-known heroes to "expand the idea of culture and its view of a hero." Looking at personal and public heroes also "helps to understand emotions and struggles." The participants' responses placed them within the theoretical and pedagogical mindset of Plutarch, Campbell $(1949 / 2008,1991)$, and Hoge (2002), who each either advocated for or used heroes as models and anti-models in the development of the individual and maturation.

\section{Discussion}

So what does this mean for teaching individual development and identity? As stated above, the participants clearly saw that heroes serve a pedagogical function. They readily identified the way that heroes serve as role models for students. Four personality characteristics of heroes were prevalent throughout the data: inspiration, bravery, perseverance, and service. This is significant because we hope to cultivate these characteristics in our students. These characteristics have an immediate positive impact in the classroom and school, as well as a long-term impact on students' lives as they transition from child to adolescent to adult. This indicates that teaching heroes can contribute to teaching individual development and identity (NCSS, 2010).

Table 5. Categories of pedagogical heroes

\begin{tabular}{|c|c|c|}
\hline Category & Examples & Count \\
\hline Rights/social & $\begin{array}{l}\text { MLK Jr., Harriett Tubman, Ruby Bridges, Rosa Parks, Eleanor Roosevelt, Malala Yousafzai, Mahatma } \\
\text { Gandhi, Nelson Mandela, Susan B. Anthony }\end{array}$ & 65 \\
\hline Presidents & John F. Kennedy, Abraham Lincoln, George Washington, George W. Bush & 19 \\
\hline Innovators/Thinkers & Wright brothers, Monet, Stephen Hawking, Shakespeare, Horace Mann & 10 \\
\hline Others & Helen Keller, Oprah Winfrey, Chris Kyle, soldiers, everyday heroes & 9 \\
\hline
\end{tabular}

Table 6. Rationales for pedagogical heroes

\begin{tabular}{llc}
\hline Rationale & \multicolumn{1}{c}{ Examples } & Count \\
\hline Serving others & Helps others, serve our country & 5 \\
Personal characteristics & Hard work, determination, overcame & 14 \\
Leadership & difficulties & 12 \\
& Great president, charismatic, led country \\
Public contributions & Fought for civil rights, non-violent, \\
& technological advances, fought for \\
& women's rights & 68 \\
\hline
\end{tabular}

These preservice teachers identified the importance of teaching about civil rights figures as heroes to serve as examples for all students. They recognized them for their significant impact on society and for their inspiration to encourage others to work for a more just society. This is significant because white students made up over $90 \%$ of the participants, and we can hope that they will act on their beliefs and teach about these Civil Rights heroes in their own classrooms.

However, it is not enough to just study about these Civil Rights figures. If teachers can shift from studying these individuals as historical figures to heroes that serve as role models for students, then we can fully realize the goals of NCSS in the Theme Individual Development and Identify. These Civil Rights figures overcame great adversity to contribute to the improvement of their nation. Campbell (2013) stated that students need positive examples and Civil Rights heroes can be inspirational models for our students to imitate as they develop into adults.

Participants listed known heroes because of their personal characteristics, but listed public heroes and pedagogical heroes for their actions and contributions. This allowed the participants to consider flawed individuals in their lists of public or pedagogical heroes. It appears that to these preservice teachers, the public good outweighs the private weakness or even public flaw. The participants indicated that teaching about flawed heroes was necessary, because it can change the mindset of students and show the students how they can grow into heroes. This idea of growth, 
including mistakes and flaws, contributes to the development of the individual and identity. It moves heroes, and the students who study them, from a static snapshot of a person in time, to an ever growing, improving individual with flaws who is capable of great good. It challenges students not to remain static with their flaws, but to move on to overcoming those flaws and continuing to contribute to their society. Teachers using heroes in this way in their curriculum echoes the way that Plutarch used his biographies to develop models of what to do or not do and how we develop and improve over time in spite of past failings (Scott-Kilvert, 1965).

Others have expressed concerns about flawed heroes (Barton \& Levstik, 2004; Dunn, 1991). The participants had an idea of how to teach about flawed heroes. They identified them as gray heroes. Gray heroes are public heroes who made significant public contributions, but had a flaw that might disqualify a personal hero from hero status. The participants were willing to accept a flawed hero if the good outweighed the bad. They even felt it was necessary to teach about gray heroes because it made heroes more real to students. The participants had different standards for personal and public heroes. They were less willing to accept flaws in personal heroes because they served as a source of personal inspiration and they could readily see the impact of the flaw. However, there appeared to be a threshold for flaws. While most would accept Thomas Jefferson as a hero even though he was a slaveholder, they were less forgiving of Hernando de Soto and Andrew Jackson because of the loss of life associated with their actions. The gray hero can serve as a role model for their contributions, but serve as an anti-role model for their flaws. Campbell (2013) stated that students need both positive and negative examples. With the gray hero, it is possible to identify both in the same individual. Finally, gray heroes serve as a reminder of the fact that all humans are a mixture of good and bad characteristics and actions, and this can directly contribute to the healthy development of student' identity.

The responses of the participants place them squarely within the ranks of those who advocate for the use of teaching heroes and hero stories to support individual development and identity. Their reasons for the pedagogical use of heroes reflect the findings, beliefs, and actions of others including Plutarch, Campbell $(1949 / 2008,1991)$, Hoge (2002), Campbell (2013). Given the opportunity, the participants possess the conceptual understanding of how to use heroes pedagogically.

\section{Conclusion: Limitations and Future Implications}

Due to the exploratory nature of this study and the sample size, we encourage further research into this topic. Our findings represent the understanding of how these preservice teachers would implement instruction of heroes and hero stories in the social studies classroom to support the NCSS Theme Individual Development and Identity. Though the ability to generalize is limited, we believe our findings lay the groundwork for further study and contribute to the research about the pedagogical use of heroes and hero stories.

We started this study from the position that it is vital for elementary and middle school students to study heroes in order to help teach the NCSS Theme Individual Development and Identity. We believe that individual development and identity is important to the complete development of civic competence. Historically, hero stories have served pedagogical functions (Campbell, 1949/2008; Campbell, 1991) and we were interested to learn how these preservice teachers conceptualized heroes and whether or not that concept would interfere with their ability to use heroes pedagogically.

We learned that these preservice teachers had a balanced concept of heroes that considered heroes as valuable to the school curriculum. They identified specific heroes and described the purposes that these heroes could serve in the curriculum. They indicated that heroes should serve as role models for students to imitate. Heroes can be role models for courage, for overcoming adversity, for contributing to the greater good of the community, for fighting for justice and equality, and for achieving great things. The preservice teachers were able to overcome the barrier of the flawed hero. Rather than shifting away from hero instruction and focusing on heroic actions, as Barton and Levstik (2004) recommend, they developed the concept of the gray hero.

This study and the findings are important because they illustrate that preservice elementary teachers are able to conceptualize heroes in such a way as to open the gate to using them for pedagogical purposes in the elementary and middle school classrooms. These findings indicate that these preservice teachers are well prepared to incorporate instruction designed to teach the NCSS Theme Individual Development and the Identity and support the development of civic competence through the study of heroes and hero stories.

\section{References}

Anastasopoulos, D., Soumaki, E., \& Anagnostopoulos, D. (2010). Adolescence and mythology. Journal of Child Psychotherapy, 36(2), 119-132. https://doi.org/10.1080/0075417X.2010.495023

Anderson, K. J., \& Cavallaro, D. (2002). Parents or pop culture? Children's heroes and role models. Childhood 
Education, 78(3), 161-168. https://doi.org/10.1080/00094056.2002.10522728

Apostolou, B., \& Apostolou, N. (1997). Heroes as a context for teaching ethics. Journal of education for business, 73(2), 121-125. https://doi.org/10.1080/08832329709601628

Baneck, M., \& Anthony, K. (2016). They need a hero! Using hero stories to build academic skills and character in adolescents. AMLE Magazine, 4(1), pp. 34-37.

Barton, K., \& Levstik, L. (2004). The moral response stance. In Teaching history for the common good. Mahwah, NJ: Lawrence Erlbaum Associates. https://doi.org/10.4324/9781410610508

Bricheno, P., \& Thornton, M. (2007). Role model, hero or champion? Children's views concerning role models. Educational research, 49(4), 383-396. https://doi.org/10.1080/00131880701717230

Campbell, J. (1949/2008). The hero with a thousand faces. Novato, CA: New World Library.

Campbell, J. (1991). The Power of Myth. New York: Anchor Books.

Campbell, K. D. (2013). Mythology as the original framework in the development of leadership principles. Journal of Leadership Studies, 7(2), 48-54. https://doi.org/10.1002/j1s.21290

Chapin, J. R. (2009). Elementary social studies: A practical guide (8th ed.). Boston: Pearson.

Dunn, L. (1991). Teaching the heroes of American history: Debunking the myths, keeping the heroes. The Social Studies, 82(1), 26-29. https://doi.org/10.1080/00377996.1991.9958302

Freedman-Doan, K. (1997, April). A Hero with a Thousand Faces: An Examination of Black and White Adolescents' Heroes and Identity Formation. Paper presented at the Biennial Meeting of the Society for Research in Child Development, Washington, D.C. Retrieved from https://files.eric.ed.gov/fulltext/ED414040.pdf

Mississippi Department of Education. (2018). 2018 Mississippi college and career readiness standards for the social studies. Jackson, MS: Author.

National Council for the Social Studies. (2010). National curriculum standards for social studies: A framework for teaching, learning, and assessment. Silver Spring, MD: Author.

Scott-Kilvert, I. (1965). Introduction. In Plutarch: Makers of Rome (pp. 7-13; I. Scott-Kilvert, Trans.). Penguin Classics.

Sullivan, M. P., \& Venter, A. (2010). Defining heroes through deductive and inductive investigations. The Journal of social psychology, 150(5), 471-484. https://doi.org/10.1080/00224540903366602

Task Force of the National Council for the Social Studies. (2010). National Curriculum Standards for Social Studies: A Framework for Teaching, Learning, and Assessment. Alexandria, VA: National Council for the Social Studies.

Thornton, S. (2005). Social Studies that matter: Curriculum for active learning. New York, NY: Teachers College Press.

White, S. H. (1999). What is a hero? An exploratory study of students' conceptions of heroes. Journal of Moral Education, 28(1), 81-95. https://doi.org/10.1080/030572499103322

\section{Copyrights}

Copyright for this article is retained by the author(s), with first publication rights granted to the journal.

This is an open-access article distributed under the terms and conditions of the Creative Commons Attribution license (http://creativecommons.org/licenses/by/4.0/). 